\author{
Aneta Kaźmierska-Patrzyczna*, Monika A. Król ${ }^{* *}$
}

\title{
PRZYRODNICZE DOBRA CHRONIONE
}

\section{Dobra prawnie chronione}

W językowym ujęciu termin „dobra” oznacza zasób środków służących rozwojowi materialnemu i duchowemu człowieka, sprzyjających postępowi ${ }^{1}$.

W teorii ekonomii dobrami określa się wszystkie przedmioty i usługi służące zaspakajaniu ludzkich potrzeb ${ }^{2}$. Dobra są klasyfikowane według różnych kryteriów: 1) według kryterium przeznaczenia dzieli się je na dobra produkcyjne i konsumpcyjne; 2) według kryterium pochodzenia na dobra pierwotne i wytworzone przez człowieka; 3) według kryterium dostępu na dobra wolne i rzadkie; 4) według kryterium korzystania na dobra prywatne, klubowe, publiczne ${ }^{3}$. Natomiast przedstawiciele neoklasycznej ekonomii środowiska traktują jako dobra zasoby naturalne, nazywane często dobrami środowiskowymi, które mają do spełnienia wiele funkcji służących człowiekowi i gospodarce ${ }^{4}$.

W naukach prawnych spotykany jest termin „dobra prawne”, oznaczający dobra materialne lub niematerialne, które są pozytywnie wartościowane społecznie, a przez to chronione prawem. Zgodnie z poglądem prezentowanym $\mathrm{w}$ doktrynie ${ }^{5}$ prawo chroni pewne wartości, które społeczeństwo zorganizowane w państwo uznaje za najważniejsze dla swojego bytu i dlatego uważa za konieczne strzec je za pomocą tak ostrych, wyjątkowych środków przymusu. Pojęcie to jest jedną

* Dr, Katedra Prawa Administracyjnego i Nauki Administracji, Wydział Prawa i Administracji Uniwersytetu Łódzkiego.

** Dr, Katedra Prawa Administracyjnego i Nauki Administracji, Wydział Prawa i Administracji Uniwersytetu Łódzkiego.

1 Słownik współczesnego języka polskiego, red. A. Sikorska-Michalak, O. Wojniłko, t. I, Warszawa 2001, s. 175.

${ }^{2}$ H. Rogall, Ekonomia zrównoważonego rozwoju. Teoria i praktyka, Poznań 2010, s. 59.

3 T. Żylicz, Ekonomia środowiska i zasobów naturalnych, Warszawa 2004, s. 37.

${ }^{4}$ H. Rogall, op. cit., s. 62.

${ }^{5}$ M. Cieślak, Polskie prawo karne, Warszawa 1995, s. 25. 
z podstawowych kategorii pojęciowych prawa karnego ${ }^{6}$. Prezentowana $\mathrm{w}$ doktrynie typologia dóbr wyróżnia dobra indywidualne (dobra jednostki np. zdrowie i życie człowieka), czy dobra uniwersalne (dobra państwa czy społeczeństwa np. obronność państwa, dobro wymiaru sprawiedliwości). Dobrami prawnymi są również przedmioty, które umożliwiają człowiekowi jego samorozwój ${ }^{7}$, ale także inne istoty żywe (zwierzęta), czy środowisko naturalne.

Prawo administracyjne materialne nie jest indyferentne aksjologicznie, stąd też powinno być nastawione na ochronę wartości lub dóbr ważnych w ludzkim współistnieniu ${ }^{8}$. Jak wskazuje Z. Duniewska, dobra są często poczytywane za ucieleśnienie wartości, są ich nośnikiem, stąd przy pewnym uproszczeniu dobra są zrównywane często z wartościami, a termin „dobra” jest używany zamiennie z określeniem „wartość"

$\mathrm{Z}$ uwagi na to, że w każdym społeczeństwie istnieją różnorodne wartości zróżnicowane ze względów społecznych, historycznych, politycznych, ekonomicznych, obyczajowych czy światopoglądowych, nie ma jednolitego katalogu tych wartości. Potrzeba zintegrowania tych różnych wartości musi polegać na ustaleniu pewnych podstawowych wartości wspólnych, określanych jako fundament aksjologiczny ${ }^{10}$. Rolą prawodawcy jest wybór tych podstawowych wartości (dóbr), uznanych w danym systemie za ważne i wymagające ochrony. Jak wskazuje S. Wronkowska, proces tworzenia prawa obejmuje wytyczenie celów, które zamierza się poprzez prawo osiągnąć. W szczególności proces ten obejmuje konkretyzowanie, a nawet niekiedy modyfikowanie systemu wartości, którego ochronie i realizacji ma służyć prawo. Powinien także obejmować kontrolowanie, czy w toku bieżącej działalności nie podejmuje się działań, które byłyby niezgodne z przyjętym systemem wartości ${ }^{11}$.

Treść dóbr prawnych podlegających ochronie może być precyzowana poprzez odwołanie do konstytucji, która zawiera odkreślony katalog wartości ${ }^{12}$. Wskazanie na konieczność ochrony pewnych dóbr znajduje także odzwierciedlenie w unormowaniach ratyfikowanych umów międzynarodowych. Jak pisał

${ }^{6}$ D. Gruszecka wskazuje na etymologię tego pojęcia prawnego z doktryny niemieckiej, zob.: taż, Ochrona dobra prawnego na przedpolu jego naruszenia. Analiza karnistyczna, Warszawa 2012, s. 19-20 i wskazana tam literatura.

7 Ibidem, s. 29-30.

${ }^{8}$ Z. Duniewska, [w:] R. Hauser, Z. Niewiadomski, A. Wróbel (red.), System prawa administracyjnego, t. VII, Prawo administracyjne materialne, red. R. Hauser, Z. Niewiadomski, A. Wróbel, Warszawa 2012, s. 127-128.

9 Ibidem.

10 Szerzej na ten temat K. Pałecki, Prawoznawstwo, Zarys wykładu: prawo w porzadku spotecznym, Warszawa 2003, s. 18 i n.

11 S. Wronkowska, Zagadnienia racjonalnego tworzenia prawa, „Studia Prawnicze” 1979, z. 2, s. 18.

12 D. Gruszecka, op. cit., s. 31, czy Z. Duniewska, [w:] R. Hauser, Z. Niewiadomski, A. Wróbel (red.), op. cit., s. 129. 
J. Wróblewski ${ }^{13}$ najbardziej ogólnie określonym celem społecznym jest utrzymanie środowiska ekologicznego człowieka w stanie najbardziej odpowiadającym jego egzystencji. Cel ten jest formułowany w następstwie zagrożeń, jakie powstawały w związku z kompleksowymi, kumulacyjnymi i długotrwałymi zamierzonymi działaniami człowieka. Ten ogólnie scharakteryzowany cel może być następnie konkretyzowany jako ochrona środowiska biologicznego człowieka, czy ochrona przyrody, jej zasobów czy tworów.

Celem autorek opracowania jest ukazanie aksjologicznych uwarunkowań ochrony dóbr przyrodniczych, wskazanie dóbr przyrodniczych jako przedmiotu ochrony prawnej w regulacjach administracyjnoprawnych, oraz ewolucji i rozszerzenia jej zakresu, a także wzrastającego znaczenia ochrony dóbr przyrodniczych w aktach prawnych podejmowanych na arenie międzynarodowej.

\section{Aksjologiczne uwarunkowania ochrony dóbr przyrodniczych}

W historycznym ujęciu wzajemne relacje pomiędzy człowiekiem i przyrodą ukształtowały się na skutek różnych oddziaływań, motywowanych religijnie, gospodarczo, czy ideowo. We współczesnej literaturze przyrodniczej ${ }^{14}$ i doktrynie prawa ${ }^{15}$ wymienia się szeroki katalog przyczyn, dla których poddano ochronie zasoby przyrody.

Geneza ochrony przyrody sięga starożytności, gdy w Egipcie czy Arabii ${ }^{16}$ chroniono twory przyrody i pewne gatunki zwierząt. Początkowo była ona motywowana względami religijnymi. Takie też względy przyświecały plemionom słowiańskim czy germańskim, dla których stare drzewa stanowiły symbol kultu ${ }^{17}$, natomiast plemiona indiańskie szczególną czcią otaczały zwierzęta. Współcześnie w niektórych społecznościach związanych z buddyzmem czy dżinizmem ${ }^{18}$, motywy religijne nadal spełniają pozytywną rolę w otaczaniu ochroną zasobów przyrodniczych. Zgodnie ze społeczną nauką Kościoła katolickiego, zarówno

13 J. Wróblewski, Reguty i oceny instrumentalne a prawna ochrona środowiska ekologicznego czlowieka, „Studia Prawno-Ekonomiczne” 1974, t. XII, s. 17.

14 E. Symonides, Ochrona przyrody, Warszawa 2007, s. 67-75.

15 J. Boć, E. Samborska-Boć, [w:] J. Boć, K. Nowacki, E. Samborska-Boć, Prawo ochrony środowiska, Wrocław 2008, s. 57-63 i wskazana tam literatura; A. Przyborowska-Klimczak, Ochrona przyrody. Studium prawno międzynarodowe, Lublin 2004, s. 30-35.

16 W Arabii czczono i chroniono jako święte drzewa oliwne, skały, głazy, Egipcjanie oddawali hołd bóstwom występującym pod postaciom zwierząt, co prowadziło do otaczania czcią wybranych gatunków, zob. A. Przyborowska-Klimczak, op. cit., s. 17, czy J. Wolski, Historia powszechna. Starożytność, Warszawa 1992, s. 34.

17 W. Szafer, Zarys historii ochrony przyrody w Polsce, [w:] W. Szefer (red.), Ochrona przyrody i jej zasobów, t. 1, Warszawa 1965, s. 53-54.

18 P. Balcerowicz, Dżinizm. Starożytna religia Indii, Warszawa 2003, passim. 
w poglądach Jana Pawła II, jak i Benedykta XVI ${ }^{19}$, zasoby przyrody zostały ofiarowane ludziom i winni oni im ochronę i szacunek. Jeszcze dalej w swoich poglądach idzie patriarcha Konstantynopola Bartłomiej, wskazując, iż: „kto szkodzi środowisku naturalnemu grzeszy przeciwko Bogu"20.

Korzyści gospodarcze z użytkowania zasobów przyrody dostrzeżono w starożytności, zwłaszcza w odniesieniu do zasobów leśnych. W wiekach średnich zdano sobie sprawę z wyczerpywania się pewnych zasobów naturalnych i konieczności ich rozsądnej eksploatacji, o czym świadczą powoływane przykłady prawodawstwa Piastów i Jagiellonów ${ }^{21}$. W wielu państwach Europy Zachodniej już w XVI w. powstały pierwsze akty prawne, których celem była ochrona zasobów leśnych, zarówno w celu spowolnienia erozji gleby, jak i zapewnienia dostaw drewna ${ }^{22}$. Pojawienie się gospodarczych przesłanek w idei ochrony przyrody nierozerwalnie wiązało się z procesem antropopresji i odkryciem przez człowieka zjawiska ograniczoności i wyczerpywalności zasobów przyrody ${ }^{23}$. Skierowało to działalność człowieka w kierunku racjonalnego gospodarowania i umiarkowanego wykorzystywania zasobów przyrody. Współcześnie ochrona przyrody, poza wszelkimi innymi przesłankami, oparta jest również na motywach gospodarczych, chociażby z uwagi na wymierny wpływ utraty zróżnicowania biologicznego na efekty ekonomiczne.

19 Zwłaszcza rozważania na temat zasad postępowania przy korzystaniu ze środowiska naturalnego Jana Pawła II, K. Dziadosz, Racjonalność ekologiczna jako kryterium stusznego prawa, [w:] R. Sobański (red.), Prawa człowieka w państwie ekologicznym, Warszawa 1998, s. 114 oraz Benedykt XVI, Encyklika Caritas in Veritate, Kraków 2009, s. 9-12. Szerzej na ten temat także S. Jaromi, Ekologia Benedykta XVI, „Eko i My” 2013, nr 5, s. 9-10.

${ }^{20}$ Bartłomiej I, Ropa i pycha, ,Tygodnik Powszechny” 2010, nr 20, s. 21. Por. też wystąpienie z okazji odebrania nagrody Peace in Terrum w dniu 12 maja 2012 r., „Tygodnik Powszechny” 2012, nr 21, s. 21. Dzięki działalności Bartłomieja I, zmierzającej do ochrony środowiska naturalnego człowieka, zyskał on miano „Zielonego Patriarchy”, por.: Jego Świątobliwość Bartłomiej I Patriarcha Ekumeniczny. Doktor Honoris Causa, KUL, „Doktorzy Honoris Causa” 2010, nr 3, s. 28.

${ }^{21}$ Poddanie ochronie bobrów przez Bolesława Chrobrego, statuty Kazimierza Wielkiego 1356-1362, statuty warckie 1420 i 1423 r., m.in. dzięki którym poddano ochronie cisy, statuty litewskie 1529 i 1588, w których poddano ochronie żubry w Puszczy Białowieskiej, przepisy wydane w 1597 r. przez Zygmunta III Wazę, w których poddano ochronie tury w Puszczy Jaktorowskiej, J. Boć, E. Samborska-Boć, op. cit., s. 15-29 czy L. Jastrzębski, Prawne zagadnienia ochrona przyrody, Warszawa 1980, s. 8.

${ }^{22}$ Zakaz wycinki drzew ustanowiony we Florencji w XVI w., francuskie rozporządzenie dotyczące lasów z 1669 r., duńskie ustawy o lasach z 1763 i 1805 r., akty prawne Piotra Wielkiego z początku XVIII w. dotyczące lasów, których celem było spowolnienie erozji gleby, jak i zapewnienie dostaw drewna, Szerzej: D. Peterson del Mar, Ekologia, Poznań 2010, s. 28-29.

${ }^{23}$ Ekonomia klasyczna nie zajmowała się specjalnie znaczeniem zasobów naturalnych dla gospodarki uznając, że powietrze, woda i inne „dary przyrody” są dostępne w nieograniczonej ilości, jednakże już w tym okresie powstała koncepcja „malejącej urodzajności Ziemi” D. Ricardo i K. Marksa, która dała podwaliny pod teorię ograniczoności zasobów naturalnych, zob. na ten temat K. Górka, [w:] K. Górka, B. Poskrobko, W. Radecki, Ochrona środowiska. Problemy ekonomiczne, społeczne i prawne, Warszawa 2001, s. 113 oraz H. Rogall, op. cit., s. 54. 
Ze względu na naturalną barierę obronną, jaką stanowiły lasy na terenach granicznych, na polskich ziemiach zachodnich od czasów pierwszych Piastów utrzymywane były obszary puszczy ${ }^{24}$. Motywy strategiczne decydowały też o obsadzaniu drzewami dróg w Prusach od XVIII w., co wpływało również na walory krajobrazowe ${ }^{25}$.

Inną podstawę aksjologiczną znajdowała działalność podejmowana przez polskich panujących i magnatów w okresie renesansu czy baroku, którzy zakładali ogrody wokół rezydencji. Był to wzgląd na motywy estetyczne, na piękno przyrody, krajobrazu ${ }^{26}$. Te pierwsze ogrody krajobrazowe przekształciły się w pierwsze parki krajobrazowe. Względy estetyczne zadecydowały o poddaniu ochronie cennych krajobrazów naturalnych, utworzeniu pierwszych parków narodowych na świecie, np. parku Yellowstone, a w Polsce objęciu ochroną wyjątkowo przyrodniczo cennych terenów, poprzez utworzenie pierwszych form ochrony przyrody w 1932 r. w Pieninach ${ }^{27}$, w Białowieży ${ }^{28}$, w Czarnohorze w Karpatach Wschodnich ${ }^{29}$. Współcześnie estetyczne motywy wiążą się z aspektem rekreacyjnym, w którym przyrodę postrzega się jako źródło radości, inspiracji i ochrania się z uwagi na jej piękno.

W wieku XIX pojawiły się także motywy patriotyczne - odwołujące się do uczuć patriotycznych i obowiązku ochrony przyrody ojczystej. Ochrona piękna przyrody powinna być jednym z elementów wychowania młodego pokolenia ${ }^{30}$. Także współcześnie można spotkać odwołania do patriotycznego obowiązku ochrony przyrody ojczystej ${ }^{31}$. Jak wskazuje A. Przyborska-Klimczak ${ }^{32}$ motywy patriotyczne i historyczno-pamiątkowe składają się na kulturowy aspekt ochrony przyrody, w którym przypisuje się jej wartość historyczną i podkreśla jej znaczenie dla zachowania świadomości narodowej.

${ }^{24}$ E. Symonides, op. cit., s. 70 oraz L. Jastrzębski, op. cit., s. 8.

${ }^{25}$ E. Piekarska, Skuteczność planowania przestrzennego w ochronie krajobrazu na przykładzie alei przydrożnych $w$ woj. warmińsko-mazurskim, Olsztyn 2008, www.fzpp.pl/asec/files/piekarska.doc (odczyt 30.07.2013).

${ }^{26}$ L. Jastrzębski, op. cit., s. 9.

${ }^{27}$ Rozporządzenie Ministra Rolnictwa z 23 maja 1932 r. o utworzeniu z rezerwatu w Pieninach jednostki organizacyjnej szczególnej pod nazwą „Park Narodowy w Pieninach”, „Monitor Polski” 1932, nr 123, poz. 156.

${ }^{28}$ Rozporządzenie Ministra Rolnictwa i Reform Rolnych z 4 sierpnia 1932 r. o utworzeniu z Nadleśnictwa Rezerwat w okręgu Dyrekcji Lasów Państwowych jednostki organizacyjnej szczególnej pod nazwą „Park Narodowy w Białowieży”, „Monitor Polski” 1932, nr 183, poz. 219.

${ }_{29}$ Park utworzony 27 września 1932 r. pismem nr 2580-U/32 Dyrekcji Naczelnej Lasów Państwowych. Szerzej: J. Kostyrko, Czarnohorski Park Narodowy, [w:] O Czarnogórze, Kraków 1933, s. $74 \mathrm{in}$.

${ }^{30}$ E. Symonides, op. cit., s. 70-71.

31 R. Kędera, M. Hysko, K. Komornik (red.), Polska przyroda - dar i obowiazek, Warszawa 2011.

32 A. Przyborowska-Klimczak, op. cit., s. 30-31. 
Natomiast motywy ideowe - często też moralne, istnieją niezależnie od wartości użytkowej i walorów estetycznych. Jako przykład wymienia się działalność rzeczników ochrony przyrody na całym świecie, którzy podejmowali działania z pobudek ideowych. Prekursorami takiej działalności byli przedstawiciele Polskiego Towarzystwa Krajobrazowego, utworzonego w 1906 r. w zaborze rosyjskim, Galicyjskiego Towarzystwa Ochrony Zwierząt czy Polskiego Towarzystwa Tatrzańskiego.

Do historycznie ukształtowanych motywów ochrony przyrody, jako szczególnego dobra, dochodzą współcześnie jeszcze względy egzystencjonalno-zdrowotne, etniczno-społeczne czy naukowe.

Motywy egzystencjalne i zdrowotne, postulują zachowanie przyrody w najlepszym stanie jako fundamentu życia człowieka i warunku jego przetrwania. Niezależnie od innych motywów, względy zdrowotne społeczeństwa winny być traktowane jako priorytet przy tworzeniu strategii, programów i aktów normatywnych odnoszących się do ochrony przyrody. Aspekt zdrowotny będzie w najbliższej przyszłości nabierał znaczenia ze względu na zwiększenie skutków chorób cywilizacyjnych i wzrastającą liczbę ludności na świecie ${ }^{33}$.

Natomiast motywy etniczno-społeczne - związane są ochroną lokalnej przyrody, często zdewastowanych zasobów naturalnych na terenach dotkniętych ubóstwem, gdzie działania te towarzyszą podstawowym zabiegom służącym rozwojowi gospodarki, zapewnieniu społeczności podstaw egzystencji ${ }^{34}$. Społeczne motywy ochrony pojawily się stosunkowo niedawno, wraz z rozwojem tzw. koncepcji trzeciej generacji praw człowieka, w której przyroda i środowisko postrzegane są jako dobro, którego ochrona jest niezbędna dla przestrzegania niezbywalnego prawa człowieka do życia w zdrowym i czystym środowisku naturalnym człowieka ${ }^{35}$.

Na zakończenie trzeba także wspomnieć o motywach naukowych z uwagi na to, że bogactwo tworów przyrody stanowi nieocenione źródło inspiracji dla badań naukowych z zakresu nauk ekologicznych, rolniczych, leśnych. Stanowi to podstawę do rozwoju biotechnologii, inżynierii genetycznej, farmacji i wielu innych dziedzin nauki. Jak wskazuje D. Jakubowska przesłanki ekologiczne i naukowe łączy się z narastającą na przestrzeni wieków skalą zjawiska wymierania gatunków roślin i zwierząt, będącą konsekwencją zachwiania naturalnej równowagi w eko-

33 E. Symonides, op. cit., 71 i 74.

34 Ibidem, s. 74-75.

35 D. Jakubowska, [w:] M. Górski (red.), Prawo ochrony środowiska, Warszawa 2009, s. 477. Tzw. „trzecia generacja praw człowieka” w systemie praw człowieka - prawo do pokoju, prawo do rozwoju, prawo do życia w czystym środowisku. Szerzej na ten temat: G. Grabowska, Człowiek i środowisko $w$ prawie międzynarodowym, „Państwo i Prawo” 1996, z. 1, s. 19-30; O aspekcie prawa człowieka do środowiska pisał W. Radecki, Obywatelskie prawo do środowiska w Konstytucji PRL, Jelenia Góra 1984, passim oraz B. Rakoczy, Ograniczenie praw i wolności jednostki ze względu na ochronę środowiska w Konstytucji Rzeczypospolitej Polskiej, Toruń 2006, s. 230 -236. 
systemach, która to doprowadziła do tego, iż człowiek zaczął dążyć do poznania praw rządzących przyrodą w celu jej ochrony przed niekorzystnymi następstwami swej rabunkowej gospodarki i przywracania w niej stanu naturalnej homeostazy ${ }^{36}$.

\section{Koncepcje ochrony dóbr przyrodniczych w ustawodawstwie polskim}

O ochronie przyrody można mówić z chwilą pojawienia się pierwszych ograniczeń w korzystaniu z zasobów przyrodniczych, chociaż jeszcze nie ze względów idealnych, lecz motywowanych względami gospodarczymi lub użytkowymi. Stąd poszukuje się zalążków prawnej ochrony przyrody w systemie królewskich regaliów łowieckich, w zakresie rybołówstwa, górniczych czy bartnych ${ }^{37}$, których bezpośrednim celem była ochrona interesów ekonomicznych panującego, a które pośrednio chroniły zasoby przed nadmiernym pozyskiwaniem. Pierwotne akty z zakresu ochrony przyrody, motywowane gospodarczo, w kolejnych wiekach stopniowo zaczęto uzupełniać motywami idealnymi, głównie przyrodniczymi, estetycznymi czy naukowymi. W I połowie XV w. pojawiły się pierwsze normy, których przedmiotem była ochrona zasobów przyrody: ograniczenia w zakresie polowań na niektóre gatunki zwierząt oraz okresy ochronne dla ich prowadzenia, ochrona gatunków poprzez ograniczenia w zakresie wyodrębnienia niektórych gatunków drzew. W XVI w. w statutach litewskich ustanawiono ochronę drzew, gniazd sokolich i żeremi bobrowych. W celu ochrony tych szczególnych dóbr przyrodniczych utworzono pierwszy w historii rezerwat turów na Mazowszu ${ }^{38}$. W II połowie XVIII w. wprowadzono pierwsze nakazy racjonalnej gospodarki leśnej. W tym okresie, ze względów estetycznych, zakładane były parki, stanowiące współcześnie nie tylko ważny element krajobrazu kulturowego, ale zbiorowiska rzadkich i cennych okazów roślinności ${ }^{39}$.

Ustanowienie w zaborze pruskim pomników i zabytków przyrody, dla ich wartości historycznej i naukowej, dało początek konserwatorskiej koncepcji ochrony, polegającej na zachowaniu cennych elementów pierwotnej przyrody ${ }^{40}$.

36 D. Jakubowska, [w:] M. Górski, J. Kierzkowska, Prawo ochrony środowiska, Bydgoszcz 2006, s. 440.

${ }^{37}$ Szerzej na temat instytucji regaliów i ich rodzajów W. Radecki, [w:] W. Radecki (red.), Teoretyczne podstawy prawa ochrony przyrody, Wrocław 2006, s. 9-12.

${ }^{38}$ Ibidem, s. 14, L. Jastrzębski, op. cit., s. 10, K. Górka, B. Poskrobko, W. Radecki, op. cit., s. 206.

${ }^{39}$ M.in. Arkadia koło Nieborowa, czy Łazienki w Warszawie, E. Więcko, Historia rozwoju ochrony przyrody i krajobrazu w Polsce, [w:] K. Buchwald, W. Engelhardt (red.), Ksztattowanie krajobrazu a ochrona przyrody, Warszawa 1975, s. 62.

40 A. Wodziczko, Na straży przyrody. Wiadomości i wskazania z dziedziny ochrony przyrody, Kraków 1948, s. 6. 
Realizacja tego celu wymagała przeprowadzenia działań inwentaryzacyjnych i ewidencyjnych, dzięki którym poznano zasoby naturalne. Jak wskazuje P. Korzeniowski ${ }^{41}$, z tego też względu wiek XIX określany jest często okresem inwentaryzacji zabytków przyrody. Jako największe osiągnięcie konserwatorskiej koncepcji ochrony przyrody wskazuje się ustawy przyjęte przez Sejm Krajowy we Lwowie w autonomicznej Galicji, w których poddano ochronie szczególnie cenne gatunki fauny tatrzańskiej, czy gatunki zwierząt uznawanych za pożyteczne dla rolnictwa ${ }^{42}$.

Całościowa ochrona dóbr przyrodniczych pojawiła się dopiero w latach 30 . $\mathrm{XX}$ w. Przenosiła ona punkt ciężkości z zabiegów ochronnych, z ochrony gatunkowej roślin i zwierząt na ochronę kompleksów przyrodniczych, ich naturalnych siedlisk i całych ekosystemów. Koncepcja biocenotyczna rozwijana była przez tworzenie obszarowych form ochrony przyrody na wzór Parku Narodowego Yellowstone, czy pierwszego w Europie Parku Narodowego Sarek w Szwecji, założonego w $1909 \mathrm{r}$.

Na początku XX w., w ustawodawstwie administracyjnym, widać było jeszcze dominację koncepcji konserwatorskiej, poprzez poddanie ochronie pomników przyrody (ustawa z 1902 przyjęta w Hesji), ochronie krajobrazu i pomników przyrody (francuska ustawa z 1902 r.). Jednakże wydane zaledwie po kilku latach ustawy w Szwecji w 1909 r., Norwegii w 1910 r. i Danii w 1917 r., poddawały ochronie indywidualne formy ochrony przyrody, ale wprowadzały także ochronę krajobrazu, gatunkową ochronę roślin i zwierząt, obszarowe formy ochrony przyrody w postaci parków narodowych i rezerwatów przyrody. Takie ujęcie zauważamy też w pierwszej polskiej regulacji prawnej - ustawie o ochronie przyrody z 10 marca 1934 r. ${ }^{43}$, odnoszącej się do ochrony idealnej. Na tej podstawie został

${ }^{41}$ P. Korzeniowski, Bezpieczeństwo ekologiczne jako instytucja prawna ochrony środowiska, Łódź 2012, s. 35.

${ }^{42}$ Ustawa z 1869 r. o ochronie gatunkowej tatrzańskich kozic i świstaków, czy ustawa z 1874 r. o ochronie niektórych zwierząt dla uprawy ziemi pożytecznych. Szerzej: W. Radecki, [w:] W. Radecki (red.), Teoretyczne podstawy...s, 14 i tenże, Ustawa o ochronie..., s. 19-20.

43 Ustawa z 10 marca 1934 r. o ochronie przyrody, Dz. U. nr 31, poz. 274 ze zm. Ustawa ta, zdaniem R. Paczuskiego, była bardzo starannie przygotowana, zarówno pod względem konstrukcji, jak i pod względem merytorycznym, co czyniło ją jedną z najbardziej nowoczesnych europejskich regulacji prawnych ochrony przyrody, R. Paczuski, Prawo ochrony..., s. 441. Zdaniem J. Ciechanowicz-McLean (Polskie prawo ochrony przyrody, Warszawa, s. 17) i W. Radeckiego (Ustawa o ochronie..., s. 22) dominowało w niej jednak ujęcie konserwatorskie. $\mathrm{Z}$ tego powodu poddał ją krytyce A. Wodziczko, wskazując iż już chwili uchwalenia ta pierwsza polska ustawa był aktem przestarzałym, gdyż punkt ciężkości ochrony przyrody kraju nie powinien polegać na konserwowaniu poszczególnych zabytków i pomników, lecz przede wszystkim na ochronie całości rodzimej przyrody i równowagi w niej panującej. Szerzej na ten temat: W. Radecki, Prawna ochrona przyrody w Polsce, Czechach i Stowacji. Studium prawno-porównawcze, Warszawa 2010, s. 66 oraz P. Korzeniowski, Koncepcje teoretyczne prawa ochrony przyrody w prawodawstwie ochronnym II Rzeczypospolitej Polskiej, [w:] D. Kopeć, N. Ratajczyk (red.), Prawo ochrony przyrody. Stan obecny, problemy, perspektywy, Łódź 2008, s. 73 i n. 
utworzony niestety tylko jeden park narodowy - Białowieski Park Narodowy i to dopiero $\mathrm{w} 1947 \mathrm{r}^{44} \mathrm{~W}$ latach 20. i 30. ustawodawca widział już także potrzebę ochrony szczególnych dóbr przyrodniczych, w ramach użytkowej ochrony zasobów w lasach ${ }^{45}$ czy w prawie łowieckim ${ }^{46}$.

Po II wojnie światowej ustawodawca przyjął założenie ochrony przyrody połączonej z planowaniem przestrzennym, realizowanej poprzez tworzenie planów, strategii i innych dokumentów planistycznych. Przejawem tej koncepcji było wprowadzenie przez A. Wodziczkę pojęcia uprawy krajobrazu, oznaczające całość zabiegów, których celem jest zachowanie, odtworzenie lub kształtowanie biologicznych i estetycznych własności krajobrazu ${ }^{47}$. Koncepcję planistyczną przyjęto $\mathrm{w}$ drugim polskim akcie prawnym $\mathrm{z}$ tego zakresu, ustawie z 7 kwietnia 1949 r. o ochronie przyrody ${ }^{48}$. Kierunek planistyczny, obejmując zasięgiem całość przyrody kraju, będącego terenem gospodarczego użytkowania, przewidywał tworzenie obszarów chronionych, które miały być wyłączone z gospodarczej działalności człowieka i wykorzystywane dla celów naukowych i społecznych ${ }^{49}$. W ustawie tej były jednak także wyraźne elementy konserwatorsko-biocenotycz$\mathrm{ne}^{50}$. Znacznie rozszerzono katalog prawnych form ochrony przyrody. Ustawa wprowadziła możliwość uznania poszczególnych tworów i ich skupień za pomniki przyrody, uznania określonych obszarów za rezerwat przyrody, utworzenia parku narodowego na określonym obszarze nie mniejszym niż 500 ha oraz ochronę poszczególnych gatunków roślin i zwierząt.

Najwyższym etapem ochrony, ochroną całości przyrody i zróżnicowania w niej panującego - ochrony bioróżnorodności - ochroną aktywną, czynną, będącą świadomym działaniem związanym z kształtowaniem przyrody i zapobieganiem potencjalnym zagrożeniom jest koncepcja ochrony różnorodności

${ }^{44}$ Rozporządzenie RM z 21 listopada 1947 r. o utworzeniu Białowieskiego Parku Narodowego, Dz. U. nr 74, poz. 469. Jak wskazuje W. Szafer w 1937 r. istniało 6 parków narodowych, utworzonych na podstawie przepisów prawa leśnego, i 180 rezerwatów przyrody, zob. tenże, Rzut oka na stan ochrony przyrody w Polsce na tle 17-letniej działalności Państwowej Rady Ochrony Przyrody, Kraków 1937, s. 10-12.

${ }_{45}$ M.in. rozporządzenie Prezydenta z 24 czerwca 1927 r. o zagospodarowaniu lasów niestanowiących własności państwa, tekst jedn. z 1932 r. Dz. U. nr 111, poz. 932 ze zm. i 22 marca 1928 r. o zagospodarowaniu lasów państwowych, Dz. U. 36, poz. 336 ze zm.

${ }_{46}$ M.in. rozporządzenie Prezydenta RP z 3 grudnia 1927 r. o prawie łowieckim, Dz. U. nr 110, poz. 934, czy rozporządzenie Ministra Rolnictwa i Reform Rolnych z 20 listopada 1935 r. o ochronie niektórych zwierząt łownych, Dz. U. nr 86, poz. 536 ze zm., w którym zakazano polowania na niedźwiedzie czy łosie.

47 Szerzej na ten temat: M.A. Król, Prawna ochrona krajobrazu wiejskiego w kontekście integracji europejskiej, „Samorząd Terytorialny” 2000, z. 10, s. 59.

48 Dz. U. nr 25, poz. 180 ze zm.

49 T. Szczęsny, Ochrona przyrody i krajobrazu. Warszawa 1975, s. 11-12;

50 J. Ciechanowicz-McLean, Polskie prawo ochrony..., s. 17 czy K. Gruszecki, Ustawa o ochronie przyrody. Komentarz, Warszawa 2010, s. 11. 
biologicznej. Powstanie tej koncepcji oparte jest na zasadzie zrównoważonego rozwoju, uwzględnia złożoność przyrody i zależności istniejących pomiędzy stanem zasobów naturalnych a rozwojem gospodarczym, jak również pomiędzy jakością elementów środowiska a jakością życia człowieka.

Sprawy ochrony przyrody będącej res omnium communnis nie są i nie mogą być zagadnieniami typu lokalnego. Jak wskazywał L. Jastrzębski, niektóre elementy wchodzące w skład pojęcia ochrony przyrody nie stanowią własności tylko jednego państwa lub narodu (powietrze, rzeki, oceany, dzikie zwierzęta czy przemieszczające się ptactwo), lecz wielu państw, a nawet wspólne dobro ludzkości ${ }^{51}$. Współcześnie międzynarodowe konwencje ekologiczne są jednym z ważnych instrumentów prawa ochrony różnorodności biologicznej ${ }^{52}$. Ich znaczenie rośnie ze względu na ponadnarodowy charakter wielu problemów ekologicznych oraz postępującą globalizację gospodarki. Ochrona różnorodności biologicznej stanowi przedmiot zarówno międzynarodowych, jak i europejskich regulacji prawnych, których stroną jest zarazem UE, jak też Polska. W ostatnich latach nie tylko zwiększa się liczba tych aktów, ale także następuje wzrost ich szczegółowości i konkretyzacja obowiązków nakładanych na strony. Kolejne, nowe zobowiązania i zadania przyjmowane są przez państwa-strony w drodze dodatkowych protokołów do konwencji. Dla ochrony zasobów przyrodniczych istotne znaczenie mają postanowienia wielu ratyfikowanych umów międzynarodowych ${ }^{53}$, m.in.: Międzynarodowa konwencja ochrony roślin, sporządzona w Rzymie 6 grudnia 1951 r. ${ }^{54}$; konwencja ramsarska - Konwencja o obszarach wodno-błotnych mających znaczenie międzynarodowe, zwłaszcza jako środowisko życiowe ptactwa wodnego, sporządzona w Ramsar w Iranie dnia 2 lutego 1971 r. $^{55}$; Konwencja o międzynarodowym handlu dzikimi roślinami i zwierzętami gatunków zagrożonych wyginięciem, sporządzona w Waszyngtonie dnia 3 marca $1973 \mathrm{r}^{56}$, zwana konwencją CITES $^{57}$; konwencja bońska o obronie wędrownych gatunków dzikich zwierząt, przyjęta w Bonn 23 czerwca 1979 r. $^{58}$; Konwencja o ochronie środowiska mor-

51 L. Jastrzębski, op. cit., s. 7.

52 Rolę i znaczenie międzynarodowego prawa ochrony środowiska dla ochrony przyrody podkreśla J. Ciechanowicz, Międzynarodowe prawo ochrony środowiska, Warszawa 2001, s. 92, czy B. Rakoczy, Prawo ochrony przyrody, Warszawa 2009, s. 36.

53 Szerszego omówienia kształtowania się ochrony różnorodności biologicznej na gruncie prawa międzynarodowego dokonują B. Poskrobko, T. Poskrobko, K. Skiba, Ochrona biosfery, Warszawa 2007, s. 183-191, czy Z. Bukowski, Prawo międzynarodowe a ochrona środowiska, Toruń 2005, s. 181-227, E. Symonides, op. cit., s. 155-174, czy T. Suski, [w:] M. Górski, J. Miłkowska-Rębowska (red.), Prawo ochrony różnorodności biologicznej, Warszawa 2013, s. 29-41.

54 Polska przystąpiła do konwencji w 1996 r., tekst ogłoszony Dz. U. z 2001 r., nr 15, poz. 151.

55 Konwencja podpisana przez Polskę w 1972 r., ratyfikowana w 1978 r. Dz. U. nr 7, poz. 24.

56 Polska ratyfikowała konwencję 12 grudnia 1989 r., tekst Konwencji Dz. U. z 1991 r., nr 27, poz. 112.

57 Szerokiego omówienia tej konwencji dokonuje B. Rakoczy, Prawo ochrony..., s. 22-25.

58 Polska ratyfikowała konwencję 1 maja 1996 r., Dz. U. z 2003 r., nr 2, poz. 17. 
skiego obszaru Morza Bałtyckiego z dnia 9 kwietnia 1992 r. $^{59}$, tzw. nowa konwencja helsińska; Ramowa konwencja o ochronie i zrównoważonym rozwoju Karpat, podpisana 25 listopada 2003 r. w Kijowie ${ }^{60}$. Największe znaczenie w tym zakresie ma jednakże Konwencja o różnorodności biologicznej, przyjęta na Konferencji Narodów Zjednoczonych „Środowisko i Rozwój” w Rio de Janeiro w dniu 5 czerwca $1992 \mathrm{r}^{6}{ }^{61}$, będąca aktem prawa międzynarodowego o podstawowym znaczeniu dla ochrony bioróżnorodności. Należy także wskazać dwa akty prawne służące lepszemu wdrożeniu jednego z zasadniczych celów konwencji, jakimi są protokół kartageński o bezpieczeństwie biologicznym do Konwencji o różnorodności biologicznej ${ }^{62}$ oraz uzupełniający go protokół z Nagoi-Kuala Lumpur o dostępie do zasobów genetycznych oraz sprawiedliwym i równym podziale korzyści wynikających z wykorzystania tych zasobów ${ }^{63}$.

Stąd też przyjmuje się uniwersalistyczną koncepcję ochrony przyrody, zakładającą, że współcześnie międzynarodowy wymiar jest najlepszym sposobem ochrony przyrody. Przejawami tej koncepcji są liczne światowe i europejskie sieci obszarów chronionych, mające na celu zintegrowanie obszarów podlegających ochronie i utworzenie spójnego systemu ochrony w poszczególnych krajach. Można w tym miejscu wskazać:

1) Sieć obszarów wodno-błotnych, tworzonych na podstawie konwencji ramsarskiej - obszarów o znaczeniu światowym z punktu widzenia m.in. ekologicznego, botanicznego, hydrologicznego. Obszary znajdujące w Spisie obszarów wodno-błotnych poddawane są szczególnemu nadzorowi i objęte programami ochrony przyrody. Polska zgłosiła 13 obszarów o pow. 145000 ha ${ }^{64}$, m.in. Biebrzański Park Narodowy, Wigierski Park Narodowy;

2) Sieć Rezerwatów Biosfery - forma ochrony przyrody zaprojektowana w ramach międzynarodowego programu badawczego UNESCO „Człowiek i Środowisko" (Man and Biosphere), obejmuje zarówno zagadnienia przyrodniczo-ekologiczne, jak również kwestie społeczne (wzrost populacji, ograniczone zasoby naturalne, degradacja środowiska, jakość i godność życia) ${ }^{65}$. Ochronie poz. 634 .

${ }^{59}$ Polska ratyfikowała konwencję w 1999 r., tekst konwencji Dz. U. z 2000 r., nr 28, poz. 346.

${ }^{60}$ Ratyfikowana przez Polskę w 2006 r., tekst konwencji ogłoszono Dz. U. z 2007 r., nr 96,

${ }^{61}$ Ratyfikowana przez Polskę w 1996 r., tekst konwencji Dz. U. z 2002 r., nr 184, poz. 1532.

62 Protokół sporządzony w Montrealu 29 stycznia 2000 r., ratyfikowany przez Polskę w 2003 r., tekst protokołu Dz. U. z 2004 r., nr 216, poz. 2201.

${ }^{63}$ Protokół sporządzony w Nagoi-Kuala Lumpur w Japonii-Malezji 15 października 2010 r., przyjęty przez UE 11 maja 2011 r. Tekst protokołu zawiera załącznik do Dz. Urz. UE L 46 z 19.02.2013, s. 4. Szerzej na temat konferencji w Nagoi: A. Erechemla, Zakończyt się światowy rok różnorodności biologicznej, „Środowisko” 2011, nr 2.

${ }^{64}$ List of Wetlands of International Importance, on 22 July 2013 r., Annotated Ramsar List, Secretariat of the Convention on Wetlandas, wwwramsar.org/Anno-list .

${ }_{65}$ B. Poskrobko, T. Poskrobko, Zarządzanie środowiskiem w Polsce, Warszawa 2012, s. 171. 
w formie rezerwatu biosfery poddaje się naturalne, zarówno wodne, jak i lądowe ekosystemy tzw. biomy, w poszczególnych regionach świata. W Polsce wyodrębniono 10 rezerwatów biosfery, w tym 4 transgraniczne, m.in. Rezerwat Jezioro Łuknajno, Rezerwat Babia Góra;

3) Sieć Obiektów Światowego Dziedzictwa UNESCO, utworzona na podstawie Konwencji w sprawie ochrony światowego dziedzictwa kulturalnego i naturalnego ${ }^{66}$. Na Listę Światowego Dziedzictwa wpisywane są tereny lub obiekty będące niezastąpionym elementem światowego dziedzictwa kulturowego lub przyrodniczego: pomniki przyrody, formacje geologiczne i fizjograficzne oraz inne miejsca niezwykle naturalnego piękna ${ }^{67}$. Z Polski wytypowano 14 takich obiektów, w tym Białowieski Park Narodowy i Park Mużakowski;

4) Europejska Sieć Ekologiczna EECONET - przyjęta przez Radę Europy w 1992 r., określana jako ,idea paneuropejskiego systemu ochrony dziedzictwa przyrodniczego" ${ }^{68}$. Kryterium identyfikacji obszarów jest ich reprezentatywność, występowanie siedlisk i gatunków typowych, rzadkich, zagrożonych z punktu widzenia zachowania europejskiego dziedzictwa przyrodniczego. W Polsce obecnie sieć pokrywa $46 \%$ powierzchni, obejmując łącznie 78 obszarów oraz łączących je korytarzy ekologicznych, m.in. mało zmienione doliny Wisły i Odry ${ }^{69}$;

5) Europejska Sieć Przyrodnicza EMERALD - sieć obszarów ważnych dla zachowania gatunków i siedlisk przyrodniczych uznanych za kluczowe na podstawie konwencji berneńskiej, tworzona na mocy Rekomendacji Stałego Komitetu Konwencji nr 16 z 1989 r. Siedliska i gatunki podlegające ochronie wymieniono w rezolucji nr 4 z 1996 r. i nr 6 z 1998 r. Przewidziana do utworzenia na terytorium całej Europy i części Afryki. W Polsce projekt zrealizowano tylko w zachodniej części kraju

6) Europejska Ekologiczna Sieć Obszarów Natura 2000 - wspólna sieć obszarów objętych ochroną przyrody w UE. Program Natura 2000 powstał w celu zachowania dziedzictwa przyrodniczego Europy. Jego podstawą są dwie unijne dyrektywy: dyrektywa 2009/147/WE ${ }^{71}$ i dyrektywa 92/43/EWG ${ }^{72}$. Głównym celem powołania sieci jest wspieranie zrównoważonego rozwoju poprzez zachowanie różnorodności biologicznej, świadome ukształtowanie relacji pomiędzy

${ }^{66}$ Konwencja paryska z 16 listopada 1972 r., ratyfikowana przez Polskę w 1976 r., Dz. U. nr 32, poz.190.

67 R. Paczuski, Prawo ochrony..., s. 458-459.

${ }^{68}$ S. Kozłowski, Ekorozwój. Wyzwanie XXI wieku, Warszawa 2000, s. 164-166.

${ }^{69}$ A. Liro, Strategia wdrażania krajowej sieci ekologicznej ECONET - Polska, Warszawa 1998, passim.

70 E. Symonides, op. cit., s. 197.

${ }^{71}$ Dyrektywa z 30 listopada $2009 \mathrm{nr}$ 147/2009 w sprawie ochrony dzikiego ptactwa, Dz. Urz. UE L 20 z 26.01.2010, s. 7.

72 Dyrektywa nr 43/92 z 21 maja 1992 r. w sprawie ochrony siedlisk naturalnych oraz dzikiej fauny i flory, Dz. Urz. UE L 206 z 22.07.1992, s. 7. 
wzrostem gospodarczym, dbałością o środowisko a zdrowiem człowieka ${ }^{73}$. Obecnie w Polsce obszary powołane w ramach sieci obejmują $6,1 \mathrm{mln}$ ha lądowej powierzchni kraju, co stanowi $19,52 \%$ powierzchni administracyjnej Polski ${ }^{74}$;

7) Paneuropejska Sieć Ekologiczna PEEN - jest głównym instrumentem Paneuropejskiej Strategii Różnorodności Biologicznej i Krajobrazowej. Decyzja o utworzeniu sieci PEEN podjęta została przez ministrów środowiska na III konferencji ministerialnej „Środowisko dla Europy” w Sofii w 1995 r. Obejmuje ona swoim zasięgiem wszystkie obszary chronione w ramach różnych inicjatyw - obszary światowego dziedzictwa UNESCO, obszary biosfery, obszary wodno-błotne, sieć EMERALD, obszary Natura 2000;

8) Bałtycki System Obszarów Chronionych HELCOM BSPA - wyznaczany od 1994 r. na mocy rekomendacji nr 15 Komisji Helsińskiej ${ }^{75}$. Głównym celem tworzenia jest ochrona przyrody morskiej, ze szczególnym uwzględnieniem zasobów biologicznych Bałtyku, poprzez ochronę gatunków flory i fauny, ich naturalnych siedlisk, ale również ochronę mechanizmów regulujących funkcjonowanie ekosystemu morskiego. Tworzenie współczesnych morskich obszarów chronionych polega przede wszystkim na racjonalnym kierowaniu działaniami człowieka, który korzysta z zasobów morskich. Do obszarów tych zostało wytypowanych 5 obszarów nadmorskich, poddanych ochronie w Polsce, poprzez ustanowienie jednej z prawnych form ochrony przyrody, m.in. Woliński Park Narodowy, Słowiński Park Narodowy;

9) Sieć PAN PARKS - sieć obszarów chronionych obejmujących swoim zasięgiem Europę i Azję, utworzona z inicjatywy World Wild Found for Nature (WWF) w $1998 \mathrm{r}$. Celem powstania sieci było stworzenie modelu parków na wzór Yellowstone i Yosemite. Wszystkie obszary włączone do tej sieci muszą spełniać ściśle określone przez Fundację PAN PARKS kryteria, które podlegają okresowej weryfikacji. Ma to służyć poprawie sposobu zarządzania tymi obszarami m.in. poprzez rozwój zrównoważonej turystyki. Status PAN PARKS posiadał Bieszczadzki Park Narodowy.

10) Sieć obszarów HNV - sieć obszarów wiejskich o wysokiej różnorodności biologicznej i krajobrazowej, tworzona w państwach UE i innych państwach w Europie. Koncepcja wyznaczania obszarów przyrodniczo cennych na terenach wiejskich (HNV) tworzona jest w oparciu o takie parametry jak: obecność półnaturalnej szaty roślinnej, mozaikowatość krajobrazu oraz niską intensywność produkcji rolniczej. Tereny te często pokrywają się z ustanowionymi na podstawie

${ }^{73}$ K. Dziubak, P. Łagodzki, M. Dziubak, Europejska sieć ekologiczna Natura 2000, [w:] A. Kaźmierska-Patrzyczna, M.A. Król (red.), Problemy wdrażania systemu Natura 2000 w Polsce, Poznań 2013, s. 17.

${ }^{74}$ Dane: „Biuletyn Komisji Europejskiej. Natura 2000” 2013, nr 33, s. 8.

75 Według danych na 2009 r. istniało 89 obszarów Helcom BSPA, które obejmowały obszar 22569 km². Dane według: Baltic Sea Environment Proceedings, Helsinki Commission - Baltic Marine Environment Protection Commission 2009, No. 116A, s. 17. 
przepisów krajowych prawnymi formami ochrony (np. parkami krajobrazowymi), ale zasadą jest, że pozostają w rolniczym i leśnym zagospodarowaniu. W Polsce obszary HNV nie zostały wyznaczone ${ }^{76}$.

\section{Dobra przyrodnicze jako przedmiot ochrony prawnej w obowiązującej polskiej regulacji prawnej}

Ustawa z 2004 r. o ochronie przyrody ${ }^{77}$, będąc kolejnym polskim aktem prawnym $\mathrm{w}$ omawianym przedmiocie, stanowi wyraz kontynuacji dotychczasowych koncepcji ochrony środowiska przyrodniczego, ale z silnym zaakcentowaniem koncepcji ochrony bioróżnorodności. Potwierdza to treść art. 2 ust. 1 u.o.p., w którym określono zakres przedmiotowy tej ochrony jako: zachowanie, zrównoważone użytkowanie oraz odnawiane zasobów, tworów i składników przyrody, a także art. 2 pkt 2, wskazujący zachowanie bioróżnorodności jako jeden z celów ustawy.

W tym ujęciu, dobrem chronionym pozostaje środowisko przyrodnicze, w którym odbywa się działalność człowieka. Odwołując się do treści art. 2, działalność ta nie może naruszać zasady zrównoważonego użytkowania zasobów przyrody. Stąd też w konsekwencji w art. 3 pkt 1 u.o.p. określony został obowiązek uwzględniania wymagań ochrony przyrody w działalności gospodarczej i inwestycyjnej. Przejawem zrównoważonego rozwoju społeczno-gospodarczego, statuowanego w art. 5 Konstytucji $R P^{78}$ w odniesieniu do ochrony przyrody, jest założenie zrównoważonego użytkowania tworów, zasobów i składników przyrody (art. 2 ust. 1 u.o.p.), zrównoważonego użytkowania różnorodności biologicznej (art. 3 ust. 4 u.o.p.) i zrównoważonego wykorzystania użytków rolnych i leśnych (art. 24 ust. 1 pkt 6 u.o.p.) ${ }^{79}$.

W ustawodawstwie polskim wyodrębnione zostały wyraźne dwa reżimy ochronne. Pierwszy, określany tradycyjnie jako „prawo ochrony przyrody”, stanowią przepisy związane $\mathrm{z}$ ochroną zasobów przyrodniczych w ujęciu konserwatorskim, idealnym. Idealna ochrona przyrody oznacza ochronę zasobów,

76 Szerzej o obszarach HNV zob.: M.A. Król, Obszary o wysokich wartościach przyrodniczych i ich znaczenie w ochronie różnorodności biologicznej na obszarach wiejskich, [w:] M. Górski, M. Niedziółka, R. Stec, D. Strus (red.), Administracja publiczna a ochrona przyrody. zagadnienia ekonomiczne, społeczne oraz prawne, Warszawa 2012, s. 56-61.

77 Ustawa z 16 kwietnia 2004 r. o ochronie przyrody, tekst jedn. z 2013 r., poz. 627 ze zm., dalej cyt. jako: ,u.o.p.”.

${ }_{78}$ Ustawa z 2 kwietnia 1997 r., Konstytucja Rzeczypospolitej Polskiej, Dz. U. nr 78, poz. 483 ze zm.

79 Szerzej na ten temat W. Radecki, Ustawa o ochronie..., s. 58; J. Ciechanowicz-McLean, Polskie prawo..., s. 33-34, J. Sommer, [w:] W. Radecki (red.), Teoretyczne podstawy..., s. 100, czy Z. Bukowski, Zrównoważony rozwój w systemie prawa, Toruń 2009, s. 482-483. 
tworów i składników przyrody, motywowaną względami konserwatorskimi, biocenotycznym, gdzie ochronę przyrody stosuje się dla niej samej, bez względu na jej wartości gospodarcze czy użytkowe, ale ze względu na interes publiczny ${ }^{80}$. W jej ramach wprowadza się rozróżnienie dwóch poziomów ochronnych: ochronę powszechną i ochronę szczególną ${ }^{81}$. Istotą ochrony powszechnej jest objęcie ochroną całej przyrody, występującej na terytorium kraju, łącznie z terenami zagospodarowanymi, w tym także terenów zdegradowanych. Wymóg ochrony całej różnorodności biologicznej, niezależnie od prawnych form tej ochrony wynika z Konwencji o różnorodności biologicznej i polega na podjęciu działań ochronnych w stosunku do dziko występujących, cennych, zagrożonych wyginięciem, rzadkich siedlisk przyrodniczych oraz gatunków zwierząt, roślin, grzybów wraz z ich ostojami i miejscami przebywania. Analizując postanowienia polskiej regulacji prawnej można wskazać: powszechną ochronę zwierząt, roślin i grzybów (art. 125 u.o.p.), powszechną ochronę drzew i krzewów, poza lasami, realizowaną przez ustawę jako ochrona terenów zieleni oraz powszechną ochronę krajobrazu.

Natomiast w ochronie szczególnej poddaje się ochronie uznane za wyjątkowo cenne elementy przyrody żywej lub nieożywionej wraz z terytorium, na którym występują. Mogą to być części krajobrazu, twory geologiczne, poszczególne drzewostany. W ramach tej szczególnej ochrony wyróżnia się ochronę obszarową, obiektową i gatunkową:

1) obszarowe formy ochrony przyrody to parki narodowe, rezerwaty przyrody, parki krajobrazowe, obszary chronionego krajobrazu, obszary Natura 2000;

2) obiektowe formy ochrony przyrody to pomniki przyrody, stanowiska dokumentacyjne, użytki ekologiczne, zespoły przyrodniczo-krajobrazowe;

3) ochrona gatunkowa roślin, zwierząt, grzybów, a także elementów przyrody nieożywionej (ochrona tworów przyrody, skał, skamieniałości i minerałów).

Ochronę tę można podzielić na ścisłą i częściową (w pewnych okresach roku, na pewnych terenach). Ponadto w zależności od miejsca przebywania chronionych gatunków może być ona realizowana poprzez ochronę in situ - w miejscach ich naturalnego występowania, oraz ochronę ex situ - ochronę poza miejscami naturalnego występowania.

Natomiast drugi reżim prawny, określany jako ochrona użytkowa, stanowią przepisy odnoszące się do gospodarczego korzystania z zasobów przyrodniczych w gospodarce rolnej, leśnej, łowieckiej i rybackiej, ale mające także na celu zachowanie różnorodności biologicznej poprzez racjonalne jej użytkowanie ${ }^{82}$. Użytkowa ochrona odnosi się do ochrony biosfery podczas gospodarczego korzystania z zasobów przyrody. Oznacza ona nakaz racjonalnego użytkowania, a często

80 J.G. Pawlikowski, Prawo ochrony przyrody, Kraków 1927, s. 4.

81 W. Radecki, Prawna ochrona przyrody w Polsce..., s. 135, 148.

${ }_{82}$ M. Górski, [w:] M. Górski, J.S. Kierzkowska, Prawo ochrony środowiska, Bydgoszcz 2006, s. $509 \mathrm{i} \mathrm{n.}$ 
także wymóg reglamentacji zasobów leśnych ${ }^{83}$, łowieckich ${ }^{84}$, ochrony gruntów rolnych $^{85} \mathrm{i}$ wód $\mathrm{w}$ gospodarce rolnej ${ }^{86}$, czy ochrony różnorodności biologicznej w zakresie żywych zasobów morskich i gospodarce rybackiej ${ }^{87}$.

Dbałość o różnorodność biologiczną terenów wiejskich, jakość i dostępność wody, funkcjonalność gleby i stabilność klimatu w gospodarce rolnej jest przedmiotem wielu regulacji prawnych, m.in. odnoszących się do rolnictwa ekologicznego ${ }^{88}$, nawozów i nawożenia ${ }^{89}$, środków ochrony roślin ${ }^{90}$. Trzeba też wziąć pod uwagę regulację zawartą w ustawie z 26 stycznia 2007 r. o płatnościach w ramach systemów wsparcia bezpośredniego ${ }^{91}$ wraz z aktami wykonawczymi ${ }^{92}$, a także ustawę z 7 marca 2007 r. o wspieraniu rozwoju obszarów wiejskich z udziałem środków Europejskiego Funduszu Rolnego na rzecz Rozwoju Obszarów Wiejskich ${ }^{93}$ i aktów do niej wykonawczych, zwłaszcza regulację odnoszącą się do programów rolnośrodowiskowych ${ }^{94}$, czy zalesiania gruntów ${ }^{95}$, a także ustawę o organizmach genetycznie zmodyfikowanych ${ }^{96}$.

${ }^{83}$ Zasady korzystania z lasów i ich ochrony reguluje ustawa z 28 września 1991 r. o lasach, tekst jedn. . Dz. U. nr 12, poz. 59 ze zm.

${ }^{84}$ Do łowiectwa i gospodarki łowieckiej odnoszą się postanowienia ustawy z 13 października 1995 r. Prawo łowieckie, tekst jedn. Dz. U. z 2013 r., poz. 1226 ze zm.

${ }^{85}$ Ustawa z 3 lutego 1995 r. o ochronie gruntów rolnych i leśnych, tekst jedn. Dz. U. z 2013 r., poz. 1205 ze zm.

${ }^{86}$ Regulacja odnosząca się do korzystania z wód, odprowadzania ścieków, czy rolniczego wykorzystania ścieków znajduje się w ustawie z 18 lipca 2001 r. Prawo wodne, tekst jedn. Dz. U. z 2012 r., poz. 145 ze zm.

${ }^{87}$ Prawne środki ochrony zasobów morza znajdują się w ustawie z 19 lutego 2004 r. o rybołówstwie, Dz. U. nr 62, poz. 574 ze zm. natomiast ochrona żywych zasobów wód śródlądowych w ustawie z 18 kwietnia 1985 r. o rybactwie śródlądowym, tekst jedn. Dz. U. z 2009 r., nr 189, poz. 1471.

${ }^{88}$ Ustawa z 25 czerwca 2009 r. o rolnictwie ekologicznym, Dz. U. nr 116, poz. 975 ze zm.

${ }^{89}$ Ustawa z 10 lipca 2007 r. o nawozach i nawożeniu, tekst jedn. Dz. U. z 2007 r. nr 147, poz. 1033 ze zm.

90 Ustawa z 8 marca 2013 r. o środkach ochrony roślin, Dz. U. z 2013 r., poz. 455.

91 Tekst jedn. Dz. U. z 2012 r., poz. 1164 ze zm.

92 Zwłaszcza przepisy rozporządzenia MR i RW z 11 marca 2010 r. w sprawie minimalnych norm, Dz. U. nr 39, poz. 211.

93 Tekst jedn. z 2013 r., poz. 173.

94 Rozporządzenie w sprawie oraz rozporządzenie MRiRW z 13 marca 2013 r. w sprawie szczegółowych warunków i trybu przyznania pomocy finansowej w ramach działania „Program rolnośrodowiskowy" objętego Programem rozwoju obszarów wiejskich na lata 2007-2013, Dz. U. z 2013 r., poz. 361.

${ }_{95}$ Rozporządzenie MRiRW z 19 marca 2009 r. w sprawie szczegółowych warunków i trybu przyznania pomocy finansowej w ramach działania „Zalesianie gruntów rolnych oraz zalesianie gruntów innych niż rolne" objętego Programem rozwoju obszarów wiejskich na lata 2007-2013, Dz. U. nr 48, poz. 390 , ze zm.

96 Ustawa z 22 czerwca 2001 r. o organizmach genetycznie modyfikowanych, tekst jedn. z 2007, Dz. U. nr 36, poz. 233 ze zm. 
Ustawodawca podkreślił jeszcze bardziej znaczenie dóbr przyrodniczych w regulacji prawnej z 2007 r. o zapobieganiu szkodom w środowisku i ich naprawie $^{97}$, uznając, że szkoda w środowisku to negatywna, mierzalna zmiana stanu lub funkcji elementów przyrodniczych, oceniana w stosunku do stanu początkowego, która została spowodowana przez podmiot korzystający ze środowiska. Szkoda, w rozumieniu tych przepisów, może dotyczyć m.in. gatunków chronionych lub chronionych siedlisk przyrodniczych (art. 6 pkt 11 lit. a) u.z.s.ś.). W tym przypadku szkoda ma polegać na znacząco negatywnym wpływie określonej działalności na osiągnięcie lub utrzymanie właściwego stanu ochrony tych gatunków lub siedlisk przyrodniczych.

\section{Podsumowanie}

Przeprowadzona analiza pozwala wnioskować, iż dobra przyrodnicze stanowią jedną z najstarszych kategorii dóbr chronionych w prawie administracyjnym. Przyroda była pierwszym i przez stulecia jedynym z elementów środowiska poddanym ochronie. Przesłanki, dla których współcześnie dobra przyrodnicze są prawnie chronione są bardzo liczne. Analiza poglądów zawartych w doktrynie ukazuje, że od samego zarania działań ochronnych w tym zakresie względy religijne, czy ideowe, przeplatały się z względami gospodarczymi. Obecnie dochodzą jeszcze koleje motywy ochrony dóbr przyrodniczych - etyczne, naukowe, egzystencjonalne, zdrowotne, etniczno-społeczne. Niezależnie od przyjętych przesłanek, wzrost świadomości i aksjologicznego znaczenia tej kategorii dóbr w ostatnim dwudziestoleciu, spowodował rozwój regulacji międzynarodowej odnoszącej się do ochrony zasobów przyrodniczych.

Analiza polskiej regulacji prawnej ukazuje ponadto, że przedmiot ochrony prawnej w zakresie dóbr przyrodniczych podlegał na przestrzenni wieków określonej ewolucji. Od ochrony wybranych, rzadkich gatunków fauny i flory, po ochronę wybranych kompleksów przyrodniczych, zachowanych w stanie naturalnym lub półnaturalnym, a następnie ochronę walorów krajobrazowych, aż w końcu po najwyższy stopień ochrony jakim jest ochrona bioróżnorodności.

Obowiązująca ustawa z 2004 r. o ochronie przyrody wprowadza wymóg kompleksowej ochrony przyrody, co jest zgodne z powszechnie przyjętą w aktach międzynarodowych koncepcją ochrony różnorodności biologicznej. Zakres przedmiotowy ustawy uległ rozszerzeniu, a to przede wszystkim na skutek dostosowania polskiej regulacji do unijnych rozwiązań prawnych w tym zakresie i podjętych przez Polskę zobowiązań międzynarodowych. Trzon ustawy wyznaczają

97 Ustawa z 13 kwietnia 2007 r. o zapobieganiu szkodom w środowisku i ich naprawie, Dz. U. nr 75, poz. 493 ze zm. 
przepisy o formach ochrony przyrody z obszerną regulacją odnoszącą się do najnowszej formy - obszarów Natura 2000. Jedną z charakterystycznych cech regulacji prawnej dotyczącej dóbr przyrodniczych jest także to, iż przyjęcie koncepcji ochrony bioróżnorodności, czy koncepcji uniwersalistycznej, nie wyklucza nadal podejścia konserwatorskiego, czy biocenotycznego. Ustanawiając kolejne płaszczyzny ochrony dóbr przyrodniczych (bioróżnorodność), wprowadzając nowe instrumentarium prawne (ochrona siedlisk) ustawodawca nadal, konsekwentnie, stosuje instrumenty prawne ustanawiane $\mathrm{w}$ pierwszej polskiej regulacji prawnej z lat 30. XX w. (parki narodowe, ochrona gatunkowa).

Niezależnie od ustanowionych form prawnej ochrony w ujęciu idealnym, obserwujemy dynamiczny rozwój użytkowej ochrony przyrody, podczas gospodarczego jej użytkowania. Ustanowione w Polsce obszarowe formy ochrony zasobów przyrodniczych uzyskały też uznanie na arenie międzynarodowej, poprzez włączenie części z nich do światowych i europejskich sieci. 